\title{
EKSISTENSI GONTOR DI TENGAH ARUS MODERNISASI PENDIDIKAN SEBUAH MODEL INOVASI KURIKULUM
}

\section{GONTOR EXISTENCE IN THE MIDDLE OF EDUCATION MODERNIZATION CURRICULUM INNOVATION MODEL}

\author{
Muslim \\ Universitas Ibn Khaldun Bogor \\ E-mail: abdzmuslim@gmail.com
}

\begin{abstract}
ABSTRAK
Penelitian ini bertujuan untuk mengembangkan model inovasi kurikulum. Kurikukum Gontor menjadi model alternatif bagi penyelenggara pendidikan. Metode yang digunakan dalam penelitian ini menggunakan pendekatan sejarah (historiografi) dengan studi pustaka. Sumber primer yang menjadi acuan dalam penelitian ini adalah buku karya Kiayi Dr. A. Syukri Zarkasyi (Gontor dan Pembaruan Pendidikan Pesantren). Adapun sumber sekunder dari berbagai referensi yang relevan lainnya. Lalu data tersebut dideskripsikan menjadi sebuah konsep kurikulum. Alhasil, di tengah kondisi carut-marut bangsa yang dirongrong oleh penjajah sebelum masa kemerdekaan, Gontor turut menyemarakkan "Kebangkitan Pendidikan di Indonesia". Saat ini pun, kurikulumnya menjadi acuan dalam implementasi modernisasi pendidikan.
\end{abstract}

Kata kunci: pesantren, modernisasi, dan kurikulum

\section{ABSTRACT}

This research aims to develop curriculum innovation model. The Gontor curriculum is an alternative model for education providers. The method used in this study using historical approach (historiography) with literature study. The primary source of reference in this study is a book by Dr. Kiayi. A. Syukri Zarkasyi (Gontor and Education Renewal of Pesantren). As for secondary sources of various other relevant references. Then the data is described as a curriculum concept. The result, in the midst of the chaotic conditions of the nation who was undermined by the colonists before the independence period, Gontor also enliven the "Awakening Education in Indonesia". Currently, the curriculum becomes a reference in the implementation of modernization of education. Keywords: pesantren, modernization, and curriculum

\section{PENDAHULUAN}

\section{Modernisasi Pendidikan Indonesia}

Geliat pembaruan (modernisasi) pendidikan di tanah air Indonesia tercinta turut mewarnai corak peradaban bangsa ini. Beberapa tahun belakangan, bermunculan lembaga-lembaga pendidikan yang "berbasis pesantren" bak jamur yang tumbuh bermunculan. Lembagalembaga pendidikan modern yang memiliki sistem dan kurikulum "terpadu" tak kalah banyaknya turut mem-booming. Sementara di sisi lain pesantren-pesantren tradisional (konservatif) mulai tumbang satu-persatu bak daun yang berguguran.

Zarkasyi (2005:161) menyebutkan bahwa pada tahun 2005 lalu terdapat kurang lebih 179-an pondok yang dikelola oleh alumni Gontor dengan sistem full Gontory. Kemudian pada tahun 2013 silam, terjadi diskusi menarik di media masa (Iskandar
Zulkarnaen: 2013) yang menyoal Ujian Nasional (UN). UN seolah-olah sebagai ritual sakral lembaga pendidikan pemerintah yang harus diikiti oleh seluruh sekolah di tanah air ini. Uniknya, ternyata saat itu sudah sekitar 200 pesantren yang berafiliasi ke kurikulum Gontory yang didirikan oleh para alumni Gontor tersebut tidak harus mengikuti UN. Bahkan ternyata sudah ada 31 sekolah semacam itu yang sudah diakui oleh pemerintah, juga tidak harus mengikuti UN.

Inilah barangkali salah satu fenomena yang menggelitik. Di satu sisi, pemerintah mengeluarkan PERATURAN MENTRI (PERMEN) no. 36 tahun 2014 tentang pedoman pendirian, perubahan, dan penutupan satuan pendidikan dasar dan menengah yang berisi 19 bab dan terdiri dari 20 pasal itu (Menteri Komunikasi dan Informatika Republik Indonesia, 2014). 
Sementara di sisi lain, lembaga-lembaga yang disebutkan di atas dengan bebasnya melaksanakan kegiatan pendidikan yang tidak mengindahkan permen tersebut.

Melihat kondisi demikian, muncullah pertanyaan, seperti apa kurikulum yang dikembangkan oleh Gontor sehingga mendapatkan peran penting sebagai penyelenggara pendidikan yang diakui oleh pemerintah? Karena permasalahan yang berkaitan dengan pendidikan sangat luas, maka pembahasan yang akan diuraikan berkaitan dengan sistem pendidikan yang ada di Gontor, yaitu seputar kurikulum yang dikembangkan oleh Gontor. Lantas, bagaimana implementasinya sehingga kurikulum Gontor tetap eksis di kancah pendidikan nasional, bahkan merambah ke dunia internasional?

Urgensi dari pembahasan ini berkaitan dengan modernisasi lembaga-lembaga pendidikan yang tak terelakkan. Mereka membutuhkan sekolah model yang bisa menjadi acuan. Arus inilah yang menyebabkan pesantren-pesantren tradisional berguguran. Selain pesantren tradisional, tidak sedikit sekolah-sekolah yang sudah terlanjur berdiri, beroperasi bahkan meluluskan siswa/ siswi, ternyata secara prosedural belum mendapatkan izin dari pemerintah setempat dengan berbagai kondisi dan alasan.

Sejatinya permasalahan pendidikan ini sepenuhnya dipasilitasi oleh pemerintah. Namun, pemerintah nampak kewalahan menyediakan lembaga pendidikan yang memenuhi kebutuhan masyarakat. Meskipun demikian, masyarakatmemangmembutuhkan dan mencari sekolah-sekolah yang bercorak khusus, tidak seperti pendidikan pemerintah yang cenderung sekuler. Inilah sebabnya mengapa perlu pembahasan yang mengupas model kurikulum Gontory. Kalau pun belum cukup untuk menjawab berbagai permasalahan di atas, setidaknya menjadi salah satu inspirasi bagi manajerial pendidikan.

\section{Pesantren, Modernisasi, dan Kurikulum}

Pada uraian di atas tersirat tiga kata kunci yang akan dibahas; pesantren, modernisasi, dan kurikulum. Pertama, menurut Zamaksyari Dhofier sang peneliti dunia pesantren seperti yang telah dikutip oleh Muthohar (2007:11), pesantren berasal dari kata "santri" yang mendapat awalan 'pe' dan akhiran 'an' yang berarti tempat tinggal santri. Selanjutnya kata pesantren umumnya disandingkan dengan kata pondok, adaptasi dari kata funduq dalam bahasa Arab yang mengandung arti asrama. Dua kata tersebut digabungkan menjadi "pondok pesantren" sehingga menjadi idiomatik yang digunakan sebagai istilah baku untuk nama lembaga pendidikan tradisional (tua) di Indonesia.

Kedua, kata modernisasi dalam Kamus Besar Bahasa Indonesia adalah proses pergeseran sikap dan mentalitas sebagai warga masyarakat untuk dapat hidup sesuai dengan tuntutan masa kini (Departemen Pendidikan Nasional, 2008: 924). Penggunaan istilah modernisasi dalam ranah pendidikan tidak identik dengan pergeseran sikap dan mentalitas secara menyeluruh. Haedari \& El-Saha, (2004:37) memandang bahwa menghubungkan pesantren dengan istilah modern seolah menjadi sesuatu yang ambigu. Menurutnya pula, pesantren identik dengan kata tradisional yang terkesan kuno. Dalam kondisi seperti ini, maka tak heran jika di pesantren tidak memperkenankan santri mendengarkan radio, televisi, bukubuku umum, majalah, apalagi komik.

Muthohar (2007:121) menjelaskan, modernisasi dalam konteks pesantren dilakukan dengan proses dinamisasi karena pembaruan yang dilakukan pesantren bukan mengganti sistem, tetapi mengandung dua proses. Pertama, tetap menggalakkan nilainilai lama yang masih relevan dikembangkan; dan kedua, memperbarui dengan nilai yang lebih baik sesuai dengan kondisi saat ini.

Tokoh akademisi UIN Jakarta dan UHAMKA, F.N., (2008:44), menjelaskan bahwa pembaruan lembaga pendidikan 
telah dimulai sejak lahirnya madrasah sebagai babak baru pendidikan Islam di Minangkabau, awal abad 20-21. Madrasah saat itu hadir sebagai reaksi ketidakpuasan para praktisi pendidikan dengan sistem pendidikan yang menggunakan cara tradisionalis. Juga merupakan kelanjutan dari proses modernisasi surau.

Ketiga, menurut Zarkasyi (2005:7778) yang mengutuip Prof. Nana Sujana, mendefinisikan kata kurikulum dalam pendidikan diartikan dengan sejumlah pelajaran yang harus ditempuh atau diselesaikan oleh anak didik guna mendapatkan ijazah. Definisi tersebut nampaknya cukup memadai, namun terkesan ambisius. Definisi semacam ini menimbulkan konotasi negatif. Jika mendapatkan ijazah menjadi tujuan akhir, bukan kecakapan hidup (skill), maka seolah-olah generasi yang dididik sekedar sampai memiliki selembar ijazah. Terlepas dari dapat ijazah atau tidak, kurikulum merupakan serangkaian pengalaman belajar yang harus ditempuh sehingga anak tersebut memiliki skill yang diberi label (legitimasi) dari keahliannya itu dengan ijazah.

Secara praktis, menurut Hamalik (2006:10), pandangan modern menjelaskan bahwa antara kegiatan intrakurikuler dan ekstrakurikuler tidak ada pemisahan yang tegas. Semua kegiatan yang bertujuan memberikan pengalaman pendidikan kepada siswa tercakup dalam kurikulum. Para pakar lainnya telah banyak memberikan kontribusi dalam merumuskan definisi kurikulum, pemerintah pun telah merumuskan definis kurikulum secara komprehensif (UU No. 20 tahun 2003); "Seperangkat rencana dan pengaturan mengenai tujuan, isi dan bahan pelajaran serta cara yang digunakan sebagai pedoman penyelenggaraan kegiatan pembelajaran untuk mencapai tujuan pendidikan tertentu" (Kementrian Pendidikan dan Kebudayaan, 2003). Dengan demikian, sebagai salah satu perangkat pendidikan, kurikulum harus dibuat dengan memperhatikan tujuan dan pencapaian hasil belajar. Tidak sekedar berupa angka dalam draf nilai, tetapi terwujud dalam keahlian (skill) tertentu.

Ketiga komponen inilah yang menjadi kata kunci dalam pembahasan selanjutnya. Sebelum mengupas kurikulum Gontor, mari kita cermati sejenak sepak terjang Gontor dalam menghadapi rintangan dan hambatan mengarungi gelombang samudra pendidikan di Indonesia. Sebagai sebuah organisasi, Gontor pun mengalami pasang surut dan jatuh bangun sehingga telah malang merintang berkiprah membangun peradaban NKRI.

\section{Sejarah Singkat Gontor}

Gontor yang kita kenal sekarang adalah pesantren tua. Meskipun demikian, Gontor tergolong pesantren modern. Pesantren ini dikenal juga dengan Pesantren Modern Darussalam Gontor (PMDG). K.H. Abdullah Syukri Zarkasi, putra pertama dari K.H. Imam Zarkasyi (pendiri Gontor) yang memimpin Gontor sejak tahun 1985 sampai sekarang. Pondok ini didirikan pada hari Senin, 12 Rabi'ul Awal 1345 H/20 September 1926 oleh tiga bersaudara; 1) K.H. Ahmad Sahal (13191386 H/1901-1977 M), K.H. Zainuddin Fannani (1336-1386 H/1905-1967 M), dan K.H. Imam Zarkasyi (1328-1405 H/19101985 M). Info serupa bisa dilihat pula di buku yang di tulis oleh pimpinan Gontor sekarang (A. Syukri Zarkasyi, 2005: 87). Pakar sejarah negeri ini mencatat pula peran mereka. Beliau (Ahmad Mansur Suryanegara, 2010: 467) menginformasikan bahwa ketiganya putra Kiyai Santoso Anom Besari. Ketiga tokoh tersebut kemudian dikenal dengan Trimurti pendiri Pondok Modern Darussalam Gontor. (Zarkasyi, 2005b)

\section{Pesantren Tegalsari Embrio dari Gontor Klasik}

Beliau melanjutkan (A. Sy. Zarkasyi: 88), pondok ini merupakan kelanjutan dari Pondok Tegalsari (nama desa) yang terletak di sebuah desa terpencil sekitar $10 \mathrm{~km}$ di sebelah selatan 
pusat kerajaan Wengker di Ponorogo, Jawa Timur. Pesantren Tegalsari didirikan pada abad ke-18 M oleh Kiyai Ageng Muhammad Besari (Bashari). Kemudian pada tahun 1742 pondok ini dipimpin oleh Kiyai Ageng Hasan Besari, cucu beliau dari putra Kiyai Ilyas yang juga menantu Sultan Pakubuwono II (1710-1749).

Layaknya air di lautan yang mengalami pasang surut, pesantren Tegalsari mencapai kemajuan pada masa kepemimpinan Kiyai Kasan Anom Besari (1800-1862 M). Namun setelah beliau wafat, Tegalsari mengalami kemunduran. Sampai sekarang Tegalsari masih ada, tetapi jumlah santrinya hanya sedikit. Lalu pada masa kepemimpinan Kiyai Khalifah, ada seorang santri yang baik dan cerdas bernama R. M. H. Sulaiman Jamaluddin, cucu Pangeran Hadiraja, Sultan Kasepuhan Cirebon. Ia diberi amanat oleh Kiyai Khalifah untuk mendirikan pondok di desa yang berjarak sekitar $3 \mathrm{~km}$ sebelah timur pondok Telagasari. Pondok tersebut sekarang dikenal dengan nama Gontor. Kisah ini pun dituangkan dalam buku beliau (A. Sy. Zarkasyi: 90).

Kisah awal pendirian Gontor banyak disebutkan di beberapa buku. Kiyai Abdullah Syukri Zarkasyi sebagai putra pelaku sejarah telah menyebutkan di bukunya Pondok Modern Dasussalam dan buku beliau lainnya Pondok Modern Darussalam Gontor, Sejarah Balai Pendidikan Pondok Modern Gontor, serta buku Gontor dan Pembaharuan Pendidikan Pesantren. Demikian pula di beberapa buku pembaruan pendidikan pesantren yang mengupas sejarah pembaruan (modernisasi) pendidikan.

Kiyai A. Sy. Zarkasyi memaparkan bahwa perintisan pondok dimulai dengan babad desa. Gontor ketika itu merupakan tanah tak bertuan, dan masih dipenuhi oleh lebatnya pepohonan serta masih banyak pula binatang yang berkeliaran di situ. Dengan serius ia menceritakan pula, "Kawasan tersebut dikenal sebagai tempat persembunyian para penyamun, para jagoan (warok-istilah Jawa), pembegal, dan orang-orang yang berperangai kotor. Karena itu kawasan tersebut dijuluki sebagai 'tempat kotor', yang dalam bahasa Jawa disebut dengan enggon kotor." Oleh karena itu menurut para alumni dan masyarakat setempat, tempat tersebut disebut dengan Gontor, singkatan dari enggon kotor.

Penamaan Gontor bukan merupakan sebuah kebetulan. Pada saat itu memang pelajaran yang diberikan hanya masalahmasalah keagamaan. Selanjutnya beliau mempertegas, "Hal ini tentunya sesuai dengan keadaan dan kebutuhan zaman itu; karena tujuan utamanya adalah mengembalikan kesadaran rakyat yang masih dipengaruhi oleh kebiasaan-kebiasaan yang melanggar hukum agama, dengan dalih: 'itu sudah menjadi kebiasaan nenek moyang,."

Sepeninggal Kiayi Sulaiman Jamaluddin, putranya yang bernama Kiyai Arham Anom Besari melanjutkan perjuangan mengurus pesantren. Saat itu santri Gontor berdatangan dari berbagai daerah sampai dari Pasundan Jawa Barat. Namun, ketika putra beliau yang bernama Kiayi Santoso Anom Besari sebagai pemimpin generasi ketiga, Gontor mulai surut. Kegiatan pendidikan dan pengajaran di pesantren pun mulai memudar. Demikian kisah runtuhnya Gontor klasik.

Peristiwa di atas tentu dapat dijadikan pelajaran berharga bagi berbagai lembaga pendidikan. Terlebih lagi di saat ini tantangan pendidikan lebih kompleks. Perlu seni agar sebuah lembaga tetap eksis. Siagian (2005:40) dalam salah satu pernyataannya menarik benang merah tentang teori manajemen. Ia memandang, "Manusia merupakan unsur terpenting dalam semua organisasi, keberhasilan organisasi mencapai tujuan dan berbagai sasarannya serta kemampuannya menghadapi berbagai tantangan, baik yang sifatnya eksternal maupun internal sangat ditentukan oleh kemampuan mengelola sumber daya manusia dengan setepattepatnya".

Dalam kasus runtuhnya Gontor klasik, ini terjadi karena minimnya persiapan regenerasi 
atau pengkaderan pengurus pesantren. Di antara sebab lainnya, barangkali saat itu memang masih minim sentuhan manajemen seperti saat ini. Sebab lainnya, kancah politik NKRI masih dibayang-bayangi oleh imperium Belanda. Hikmah dari runtuhnya Gontor klasik ini menjadi pelajaran berharga bagi generasi baru bangsa. Ternyata kemunduran Gontor disebabkan oleh tiadanya antisipasi terhadap penyiapan kader-kader yang akan melanjutkan perjuangan pondok pada masa mendatang, kata K.H. DR. Abdullah Syukri Zarkasyi, M.A. pimpinan Gontor saat ini. Beliau menambahkan pula, di samping ketiadaan regenarasi penerus Gontor, suasana penjajahan turut memberikan kontribusi bagi mundurnya Gontor seperti pondokpondok lainnya pada waktu itu. Demikianlah gambaran singkat sejarah awal Gontor yang dituangkan oleh cucu mendiang para pendiri Gontor (Zarkasyi, 2005a)

\section{Gontor Modern}

Sumber yang sama menginformasikan pula (Zarkasyi, 2005a:91-92 dan http:// www.gontor.ac.id/pembukaan-tarbiyatulathfal-1926), ketika Gontor klasik runtuh, kondisi masyarakat Islam saat itu memprihatinkan; akhlaknya runtuh, pendidikannya mundur, dan standar hidup jauh di bawah garis kemiskinan. Keadaan ini membangkitkan tiga bersaudara putra Kiyai Anom Besari; Ahmad Sahal, Zainuddin Fannani, dan Imam Zarkasi bermodalkan masjid tua dan tanah warisan orang tua. Lalu dibukalah Tarbiyatul Athfal (TA) pada tahun 1926.

Langkah tersebut mendapat respon positif dari masyarakat sehingga dimulailah babak baru kehidupan Gontor sebagai lembaga pendidikan. Ketika itu siswa diajarkan materimateri dasar agama Islam, bimbingan akhlak, kesenian, dan pengetahuan umum sesuai dengan tingkat pengetahuan masyarakat. Demikian penjelasan Kiyai Abdullah Syukri Zarkasyi yang terus berupaya menggambarkan kondisi Gontor yang mulai mendapat kembali kepercayaan masyarakat ketika itu. Beliau pun menambahkan anakanak diajarkan pula cara menjaga kebersihan diri, cara bekerja seperti bercocok tanam dengan langsung praktek mengelola sawah, beternak ayam dan kambing, pertukangan kayu dan batu, bertenun, dan berorganisasi (Zarkasyi, 2005a:92-93).

Antusias masyarakat menyambut Gontor membludak sampai akhirnya Gontor harus membuka cabang di desa-desa lain. Kisah praktis perjalanan TA bisa diakses melalui http://www.gontor.ac.id/pembukaantarbiyatul-athfal-1926 yang ringkasan kisahnya sebagai berikut (dengan sedikit edit sebagian teks): Para santri TA itu dididik langsung oleh Pak Sahal (panggilan populer untuk K.H. Ahmad Sahal). Alas tikar dan daun kelapa menjadi saksi bisu proses KBM. Siang hari mereka belajar di bawah dan di antara pepohonan di alam terbuka, sedangkan pada malam hari mereka belajar diterangi oleh lampu batok (tempurung kelapa).

Berkat kegigihan dan keuletan beliau, pada tiga tahun pertama para santri yang belajar di Pondok Gontor telah mencapai jumlah 300. Mereka belajar tanpa dipungut biaya apapun. Bahkan tidak jarang pengasuh Pondok yang memenuhi keperluan seharihari mereka. Pada prinsipnya, tujuan utama pembelajaran di TA adalah penyadaran siswa terhadap pemahaman dan pelaksanaan ajaran agama.

Perjuangan yang meletihkan dan menyita waktu nampaknya tak sia-sia. Setelah tujuh tahun, siswa TA telah mencapai 500 orang putra dan putri dengan fasilitas belajarmengajar belum mencukupi sehingga mereka belajar di rumah-rumah penduduk dan sebagian masih di alam terbuka di bawah pepohonan. Sungguh suasana pendidikan yang mengharukan dan menjadi kenangan yang membanggakan.

Tekad membuat bangunan untuk ruang kelas semakin menguat, tetapi dana tidak ada, karena selama sepuluh tahun pertama siswa tidak dipungut bayaran apapun. Untuk 
memenuhi kebutuhan dana pembangunan dibentuklah "Anshar Gontor", yaitu orangorang yang bertugas mencari dana di seluruh wilayah Jawa. Selain itu para santri di dalam Pondok juga dilibatkan dalam pembuatan batu merah. Sementara TA terus berkembang seiring dengan meningkatnya minat masyarakat untuk belajar.

Cabang-cabang TA di desa-desa sekitar Gontor ditangani oleh para kader yang telah disiapkan secara khusus melalui kursus pengkaderan. Di samping membantu pendirian madrasah-madrasah TA tersebut. Uniknya, mutu TAdi Gontor juga ditingkatkan agar para lulusannya memiliki kemampuan yang memadai untuk ikut berkiprah membina beberapa TA cabang yang ada. Untuk itu dibukalah jenjang pendidikan di atas TA yang diberi nama Sullamul Muta'allimin (tangga para pelajar).

Menurut Kiyai Abdullah Syukri Zarkasyi, kondisi di atas hanya berlangsung sampai tahun 1936. Beliau memaparkan bahwa pada tingkatan ini mereka diajari secara lebih dalam dan luas pelajaran fiqih, hadits, tafsir, terjemah al-Qur'an, cara berpidato, cara membahas suatu persoalan, juga diberi sedikit bekal untuk menjadi guru berupa ilmu jiwa (psikologi) dan ilmu pendidikan. Pendidikan diwarnai pula dengan adanya kegiatan ektrakurikuler seperti klub-klub dan organisasi keterampilan, kesenian, olahraga, kepanduan, dan lain-lain.

Pada tahun yang sama, tepatnya tanggal 19 Desember 1936 di acara syukuran pondok yang sudah mencapai 10 tahun, diresmikanlah penggunaan sebutan modern untuk pondok Gontor. Pada saat itu pula diresmikan sistem pendidikan baru, yaitu Kulliyatul Mu'allimîn al-Islâmiyah (KMI-Sekolah Pendidikan Guru Islam). Bagian inilah yang selanjutnya dibahas lebih mendalam untuk menjawab rumusan masalah yang diajukan pada bagian pendahuluan.

Gontor ketika itu di ambang kesusksesan yang mengantarkan kepada kebesaran masa depannya. Pada tanggal 12 Oktober 1958 di acara empat windu, para pendiri pondok mewakafkan pondok miliknya kepada umat Islam yang diwakili oleh anggota Ikatan Keluarga Pondok Modern (IKPM). Kemudian dibentuklah lembaga badan wakaf. Sejarah kepemilikan pondok pun bergulir dari kepemilikan pribadi menjadi kepemilikan institusi.

Setelah itu Gontor semakin berkembang. Setelah seperempat abad KMI berdiri, dibukalah Perguruan Tinggi Dârussalâm (PTD), tahun 1963. Selanjutnya pondok terus berkembang sampai membuka 10 cabang di sekitar Jawa Timur, Jawa Tengah, Sulawesi, Lampung, dan Aceh. Saat ini (2005) cabang resminya mencapai 13 pondok. Selanjutnya pada tahun 2016 sudah lebih dari 30 cabang di Indonesia berkat peran para alumninya.

\section{HASIL PENELITIAN DAN \\ PEMBAHASAN \\ Kurikulum Gontor sebagai Model Pendidikan Modern}

Secara khusus, bagian ini mengupas tentang kurikulum Gontor (Zarkasyi, 2005a:119130). Kulliyatul Mu'allimîn al-Islâmiyah (KMI) didirikan pada tanggal 19 Desember 1936. KMI bertanggung jawab sepenuhnya atas penyelenggaraan kegiatan belajarmengajar pada tingkat menengah dengan masa belajar 6 tahun (bagi lulusan SD) dan 4 tahun (bagi lulusan SLTP/SLTA/PT). Kegiatan belajar diselenggarakan setiap hari selama 6 jam pelajaran, perjam 45 menit, mulai dari jam 07.00-12.30 WIB. Istirahat santri jam 08.30-09.00 dan 10.30-11.00.

Menurut pemaparan beliau pula (Zarkasyi, 2005a:125-130), kurikulum yang ditempuh oleh santri selama belajar di Gontor terbagi menjadi beberapa bidang studi sebagai berikut: 1) Bahasa Arab dengan bahasa pengantar berbahasa Arab; al-imlâ, alinsyâ', Tamrîn al-Lughâh, al-Muthâla'ah, al-Nahwu, al-Sharf, al-Balâghah, Târikh al-Adab, dan al-Khâth al-'Arabi. 2) Dirasah Islamiyah untuk kelas II ke atas dengan materi berbahasa Arab; al-Qur'ân, al-Tajwîd,

Jurnal Penelitian Pendidikan 
al-Tauhîd, al-Tafsîr, al-Hadîts, Musthalâh alHadîts, al-Fiqh, Ushûlal-Fiqh, al-Farâ'id, alDîn al-Islâmi, Muqâranât al-Adyân, Târikh al-Islâm, al-Mantiq, Tarjamah al-Qur'ân. 3) Keguruan; al-Tarbiyah wa al-Ta'lim berbahasa Arab dan Psikologi Pendidikan (dengan bahasa Indonesia). 4) Bahasa Inggris (dengan bahasa Inggris); Reading and Comprehension, Grammar, Composition, dan Direction. 5) Ilmu Pasti; Berhitung, Matematika, Ilmu Pengetahuan Alam, Fisika dan Biologi. 6) Ilmu Pengetahuan Sosial; Sejarah Nasional dan Dunia, Geografi, Sosiologi, dan Psikologi Umum. 7) KeIndonesiaan/Kewarganegaraan; Bahasa Indonesia dan tata Negara.

Teknis Pembaruan kurikulum dilakukan secara terus menerus dengan merevisi atau mengganti pelajaran yang tidak lagi relevan dengan kebutuhan, khususnya dalam materi pelajaran umum yang memang cenderung berkembang dengan cepat. Pembaruan kurikulum tersebut menggunakan prinsip (terjemah bebas) "Melestarikan sistem lama yang bagus dan menerapkan sistem baru yang lebih baik" yang dalam bahasa Arab: almuhâfazhah 'alâ al-qadîm al-shâlih wa alakhdzu bi al-jadîd al-ashlâh. Perubahan bisa berlaku cepat jika perubahan itu menyangkut materi-materi yang bersifat "umum," tetapi terhadap materi-materi "agama" maka perubahan dilakukan dengan sangat hati-hati.

Pembaruan kurikulum KMI ini bersifat integratif yang memadukan ilmu umum dan ilmu agama. Jadi pengajaran ilmu umum tidak terlepas dari dasar dan nilai agama, dan sebaliknya pengajaran ilmu-ilmu agama dikembangkan sejalan dengan perkembangan keilmuan umum. Demikian pula pada kurikulum intra dan ekstra. Perhatian terhadap kegiatan-kegiatan ekstrakurikuler tidak kalah dengan kegiatan-kegiatan intrakurikuler, dan demikian pula sebaliknya. Bahkan tanpa ragu-ragu dapat dikatakan bahwa dimensi ekstrakurikuler merupakan kekuatan utama dunia pesantren. Inilah salah satu faktor yang membuat Gontor tetap eksis sampai saat ini, yaitu perpaduan ilmu umum dan agama (Zarkasyi, 2005a:125-126).

Kiyai Abdullah Syukri Zarkasyi selaku pimpinan pesantren Gontor saat ini mengakui bahwa ide pembaruan sistem pendidikan pesantren sudah diterapkan sejak pembukaan Gontor yang pertama (modern) yang ditandai dengan pendirian Tarbiyatul Athfâl (1926). Adapun bentuk final pembaruan kurikulum dengan sistem Kulliyatul Mu'allimîn alIslâmiyah (KMI), tahun 1936. Beliau menegaskan (Zarkasyi, 2005a:113):

Dalam sistem Mu'allimîn inilah, integrasi antara pendidikan pesantren dengan sistem pendidikan modern dilakukan secara sepenuhnya. Sistem pesantren diambil dari warisan leluhur para pendiri pesantren pada umumnya, sedangkan sistem sekolah diambil dari sekolah Noormal Islam di Padang Panjang yang dikelola oleh Mahmud Yunus; di mana Pak Zar, salah seorang pendiri Gontor, mengenyam pendidikannya sebelum kembali ke Gontor untuk mendirikan KMI.

Jika demikian jelaslah bahwa Gontor merupakan pesantren modern sesuai dengan pernyataan pimpinannya sendiri. Tentunya pernyataan ini didukung pula dengan implementasi kurikulum Gontor (KMI) yang pada awalnya mendapatkan pandangan sebelah mata dari berbagai kalangan. Meskipun demikian, akhirnya Gontor tetap eksis sesuai dengan ciri khas kemodernannya itu. Tetapi modern yang dimaksud di sini hanya bersifat sistematika praktis, bukan content materi yang diajarkan seperti aqidah, syari'ah, atau cara ibadahnya (Zarkasyi, 2005a:116). Hal ini pernah pula dimuat di Boekoe Peringatan 15 Tahun Pondok Modern Gontor Ponorogo Java terbitan Gontor tahun 1942, hlm. 27 yang menegaskan bahwa modernisasi dalam hal ini adalah modernisasi sitemnya: kelembagaan dan organisasinya, manajemennya, kurikulumnya, dan metode pendidikannya.

Pada pembahasan makalah ini hanya 
dibahas ciri khas kemodernannya itu sebatas pada pengembangan kurikulum. (Zarkasyi, 2005a:115) menegaskan pula bahwa Kurikulum yang dimaksud adalah penerapan sistem belajar secara klasikal; penggunaan kurikulum yang bukan hanya berisi pelajaran agama, tetapi juga memuat pelajaranpelajaran umum; penggunaan bahasa asing bukan hanya Arab, tetapi juga Inggris dan Belanda; penyelenggaraan kegiatan-kegiatan ekstrakurikuler dengan aneka macam bentuknya; pelaksanaan disiplin yang ketat dengan pemberian sanksi kepada mereka yang melanggar; para guru dan santri yang memakai jas, dasi, dan celana panjang.

Ternyata praktek pendidikan semacam ini sangat asing dan tidak populer pada masa itu. Sebagai akibatnya, pondok saat itu tidak hanya menerima kritik, gunjingan, dan ejekan, tetapi santri yang sebelumnya sudah berjumlah ratusan, secara berbondongbondong meninggalkan pondok. Sehingga pada awal tahun pendirian KMI, santri Gontor hanya tinggal 16 orang (Zarkasyi, 2005a:115).

\section{Gontor Terasing di Negeri Sendiri}

Pesantren yang sudah mulai kembali tumbuh besar seketika runtuh tak berdaya. Ibarat pohon yang sudah tumbuh besar tiba-tiba tumbang lantaran badai datang menghadang. Kurikulum yang mulai dikembangkan mendapat penolakan masyarakat hingga santri nyaris habis kembali turun drastis. Meskipun demikian, dengan besar hati Zarkasyi (2005a:116) menyatakan:

Setelah melalui perjuangan yang panjang dengan kesabaran, keuletan, kesungguhan, perjuangan, dan pengorbanan yang tiada henti, akhirnya sistem Gontor mulai dapat diterima oleh masyarakat. Santri Gontor lambat laun terus bertambah, dan Gontor sendiri juga terus berkembang. Pengakuan dari berbagai pihak pun akhirnya diterima; baik dari dalam maupun dari luar negeri.

Nampaknya ada pesan tersirat yang ingin disampaikan, mengapa pengakuan itu justru lebih dulu datang dari luar negeri? Karena baru-baru ini saja Gontor mendapatkan pengakuan resmi pemerintah Indonesia melalui Depatemen Agama tahun 1998 dan Departemen Pendidikan Nasional tahun 2000 (Zarkasyi, 2005a:99-116). Maka dalam diskusi-diskusimenarik diduniamaya, banyak pihak yang mendukung eksistensi Gontor seperti yang di-upload pada link Iskandar Zulkarnaen, Mengapa di Gontor Tidak Ada Ujian Nasional? posted 24 April 2013 (updated 28 Juli 2015 jam 16:13), http://m. kompasiana.com/iskandarjet/ mengapa-digontor-tidak-ada-ujian-nasional-bagian4 552903abf17e6126268b4 6c5\#sidr-main:

Kurikulum KMI yang digunakan untuk siswa kelas 1-6 tingkat menengah di Gontor sudah lama mendapat pengakuan dari Kementerian Pendidikan dan Pengajaran Mesir (1957) dan Kementerian Pengajaran Kerajaan Arab Saudi (1967). Dengan pengakuan tersebut, lulusan Gontor bisa meneruskan studi ke jenjang sarjana di Universitas Al-Azhar Mesir dan Universitas Islam Internasional Madinah, Saudi Arabia.

Fakta di atas belum cukup membuka mata pemerintah Indonesia ketika itu untuk memberi apresiasi positif sehingga berlarutlarut Gontor berjalan mandiri sampai puluhan tahun lamanya. Dengan demikian, KMI tidak langsung sekejap mata mendapatkan tempat di hati pemerintah. Sehingga, Gontor baru diakui bangsa sendiri dua dekade terakhir. Sumber yang sama menyebutkan pula bahwa sebelumnya, dua kampus lain yang menerima ijazah Gontor adalah Universitas Islam Antarbangsa Malaysia (IIUM) sejak tahun 1983, dan University of the Punjab (PU), Lahore, Pakistan, sejak 1991.

Idealnya apresiasi positif pemerintah kita kepada Gontor sudah sejak puluhan tahun yang lalu. Keterlambatan ini menunjukkan kerangka berpikir (paradigma) individuindividu pemerintah kita masih sekuler. Pendidikan agama (Islam) di negeri kita tidak mendapat porsi yang layak. Maka cukup 
mengherankan jika maha karya anak bangsa tadi terabaikan. Muncullah pertanyaan serius yang patut diutarakan, masihkah bangsa kita terpengaruh cara berpikir (ideologi) penjajah Belanda yang ingin menjauhkan mayoritas muslim dari ulama, sekolah Islam dan kitabkitab warisan para ulama?

Jawabannya, di madrasah-madrasah yang di kelola oleh Kemenag, tidak. Tetapi di sekolah-sekolah yang dikelola oleh Diknas, benar-benar sekuler. Maka konsekwensi terburuknya adalah upaya pendidikan karakter sekedar isapan jempol belaka. Nyaris sulit untuk mengimplementasikan pendidikan yang membentuk skill dan "manusia yang beradab" seperti tertuang dalam sila ke-2 dalam falsafah negara, pancasila.

\section{Refleksi Implementasi Kurikulum Gontor}

Seorang guru yang mengajar dengan baik, menyenangkan dan disukai muridmurid (smart teacher), itu hal yang biasa. Lulusan KMI telah dicetak menjadi manusia yang mampu berkiprah di masyarakat. Meskipun setingkat SLTA, lulusannya telah mendapatkan materi-materi inti pendidikan (Tarbiyah) dan melewati microteaching yang diperlukan oleh seorang guru/pendidik. Tak heran jika salah satu skill-nya, santri KMI Gontor mampu menjadi super smart teacher pada saat mengaplikasikan keilmuan yang pernah dipelajari di kelas-kelas junior.

Implementasi program ini diterapkan dan dikembangkan pula di berbagai pesantren yang berafiliasi kepada Gontor. Salah satunya, Pesantren Islam Hidayatunnajah Bekasi yang telah lama pesantren ini mengadopsi kurikulumnya terutama program KMI Gontor di atas. Santri senior di Hidayatunnajah mendapatkan pengalaman mengajar di kelas-kelas junior dengan berbahasa Arab atau Inggris sebagai bahasa pengantar dalam proses pembelajaran. Sebelum terjun ke kelas-kelas, para santri senior ini mendapatkan bimbingan secara intensif dengan terlebih dahulu membuat rencana pembelajaran (I'dâd 'Amaliyah at-Tadrîs).
Ketika proses pembelajaran dilakukan, teman-teman sejawat dari para santri senior tersebut mengamati dan mengambil data untuk disampaikan dalam kritik (naqd) setelah proses pembelajaran selesai bersama guru pembimbing.

Pada saat naqd, teman-teman sejawat yang mengambil data selama proses pembelajaran memberikan saran, masukan, atau ide yang dapat menciptakan proses pembelajaran yang lebih efektif dan menarik lagi kepada rekannya yang baru saja melaksanakan AT sehingga menjadi inspirasi bagi para santri senior berikutnya. Demikian selanjutnya, santri senior lainnya yang akan mendapatkan jadwal mengajar mendapatkan apresiasi yang sama dalam proses naqd tadi. Praktek pembelajaran demikian inilah yang dikembangkan oleh Universitas Pendidikan Indonesia (UPI) Bandung.

Oleh karena itu, penelitian ini didukung pula dengan hasil pengamatan di Pesantren Islam Hidayatunnanah Bekasi (AgustusOktober 2016) yang terkait dengan implementasi program 'Amaliyah at-Tadrîs (AT). Dari pengamatan tersebut, diketahuilah bahwa AT merupakan proses pembelajaran yang dilakukan oleh para santri senior seperti model pembelajaran lesson study yang dikembangkan oleh UPI. Jadi, lesson study yang dikembangkan UPI sejak tahun 1998 telah dikembangkan pula dalam program AT sejak kurikulum KMI digagas oleh para pendahulu Gontor. Perbedaannya, AT diterapkan pada siswa usia SLTA, sedangkan lesson study diterapkan kepada para sarjana di berbagai lembaga pendidikan.

Suharsimi

Arikunto

(2010:136) menjelaskan bahwa lesson study adalah pendekatan pembelajaran yang dipopulerkan oleh Jepang. Beliau menyimpulkan bahwa lesson study merupakan sebuah "penelitian pembelajaran" yang dilakukan oleh sekelompok orang dengan mencermati proses pembelajaran untuk mengetahui apakah proses tersebut sudah baik sehingga memberikan dampak kepada prestasi 
belajar. Dalam perkembangan penelitian pembelajaran, lesson study sama populernya dengan penelitian tindakan kelas (PTK). Oleh karena itu, ia mengumpamakan keduanya seperti "saudara sekandung". Perbedaannya terdapat pada pengamat dalam lesson study terdiri dari beberapa orang (kelompok), sedangkan pada PTK hanya seorang saja.

Satu catatan penting yang perlu dikembangkan bersama bahwa untuk menjadikan peserta didik memiliki skill, tidak perlu sampai lulus S1. Sejak usia SLTP semestinya pendidikan kita sudah mengarah kepada pendidikan skill selain pendidikan adab dan karakter. Kurtilas yang baru saja digulirkan, mudah-mudahan dapat menjadi wasilah pencapaian tujuan pendidikan yang diharapkan. Adapun program-program lainnya yang harus ditempuh agar mencapai kematangan lulusan Gontor adalah; Fath al-Kutub (latihan membaca kitab untuk membahas sebuah permasalahan), Fath alMu'jam (membuka kamus), Manasik al-Haj, dan al-Rihlah al-Iqtishâdiyah (economic study tour). Program-program semacam ini telah membuat para alumni Gontor mampu berkecimpung di masyarakat luas. Di antara mereka, kini menjadi orang-orang yang akrab ditelinga masyarakat adalah:

1. Abdurrahman Mohammad Fachir, Duta Besar Indonesia untuk Arab Saudi

2. Abu Bakar Baasyir, Pimpinan Pondok Pesantren Ngruki, Solo

3. Adnan Pandu Praja, Wakil Ketua Komisi Pemberantasan Korupsi (KPK)

4. Ahmad Fuadi, Novelis

5. Din Syamsuddin, Ketua Umum PP Muhammadiyah dan Ketua Majelis Ulama Indonesia

6. Emha Ainun Nadjib, Budayawan

7. K. H. Hasyim Muzadi, mantan Ketua Umum PB Nahdhatul Ulama (NU)

8. M. Hidayat Nur Wahid, Mantan Ketua MPR RI

9. Idris Abdul Shomad, Wakil Walikota Depok periode 2011-2016.

10. Lukman Hakim Saifuddin, Menteri

\section{Agama}

11. Muhammad Maftuh Basyuni, Duta Besar Indonesia untuk Arab Saudi, Menteri Agama Kabinet Indonesia Bersatu

12. Muhammad Muzammil Basyuni, Duta Besar Indonesia untuk Republik Arab di Suriah

13. Nurcholis Madjid, Cendekiawan Muslim.

14. Yudi Latief, aktivis dan cendekiawan muda. Banyak lagi alumni yang tidak bisa disebutkan di sini.

(https://id.wikipedia.org/wiki/Pondok_ Modern_Darussalam_Gontor)

Sejarawan bangsa ini, Suryanegara (2010::469) turut merekam eksistensi Gontor dan kiprahnya di masyarakat. Menurutnya, di Pondok Pesantren Modern Dârussalâm Gontor ini, para ulama menempuh cara lain dalam meredakan perbedaan paham, yaitu dengan mencerdaskan generasi umat, bukan dengan debat terbuka. Para ulama tersebut mengubah metode pendidikan dan pengajaran dengan kurikulumnya.

Beliau memandang content kurikulum yang diajarkan oleh Gontor mengajarkan pandangan keseluruhan madzhab. Cara ini dapat memberikan kedewasaan dalam memahami sumber perbedaan. Sehingga jelaslah bagi santri bahwa sumber perbedaan ada pada sistem pemahaman dan metode (manhaj) dalam memahami al-Qur'an dan hadits, bukan terletak pada al-Qura'an dan haditsnya.

Jika ditarik benang merah, dikaitkan dengan fakta sejarah, mengapa pemerintah tidak merespon positif Gontor ketika itu, karena suasana politik pemerintah masih terkekang oleh ideologi penjajah (Belanda). Mereka tidak menginginkan kaum muslim dekat dengan ulama, sekolah Islam dan kitab-kitab warisan para ulama. Pandangan semacam ini telah dimuat pula dalam majalah Wardun Gontor pada tahun 2007 lalu sebagai berikut:

Dengan perubahan kurikulum itu, terbentuklah kepribadian santri yang Jurnal Penelitian Pendidikan 
memiliki self confidence (kepercayaan diri), berwawasan keagamaan yang luas, dan juga menguasai bahasa Arab dan bahasa Inggris. Secara tidak langsung, pembaharuan kurikulum pengajaran itu menentang program pemerintah colonial Belanda yang ingin tetap menjadikan umat Islam bodoh dan merasa rendah diri atau mengidap inferiority complex, dengan melarang umat Islam menguasai bahasa asing Barat. Hanya dengan cara memperbodoh umat Islam sebagai mayoritas pribumi, ditargetkan kerajaan penjajahan Kerajaan Protestan Belanda menjadi abadi di Nusantara Indonesia.

\section{SIMPULAN}

Sepak terjang PMDG yang hampir satu abad dalam mengarungi samudra pendidikan bangsa ini telah banyak memberi sumbangsih yang berharga kepada bangsa dalam memperbaiki peradaban bangsa Indonesia. Kurikulum yang dikembangkannya berhasil mewarnai ideologi pemikiran para alumni sehingga telah banyak berkiprah bagi kemajuan-kemajuan bangsa dalam berbagai lini kehidupan masyarakat.

Model pendidikan PMDG yang telah diuraikan pada pembahasan Kurikulum KMI menjadi inspirasi bagi para penyelenggara satuan pendidikan di tengah-tengah arus modernisasi pendidikan. Modernisasi yang diusung tidak membuat PMDG menjadi corong arus kebebasan dalam pemahaman keagamaan, tetapi kemodernan yang hanya terkait dengan sistem pendidikannya, bukan konten nilai-nilai ke-Islaman. Meskipun demikian, penanaman nilai luhur ke-Islaman masih perlu diperkokoh kembali lantaran tidak sedikit alumni yang mudah terbawa arus pemikiran ektrim dan yang terlampau bebas tanpa batas.

Bagaimanapun, di tengah-tengah kondisi carut-marut bangsa yang dirongrong oleh penjajah Belanda sebelum masa kemerdekaan, PMDG turut menyemarakkan "Kebangkitan Pendidikan di Indonesia" yang dipelopori oleh para tokoh dan ormas-ormas Islam seperti al-Irsyad, Muhammadiyah, NU, Persis, dan yang lainnya. Oleh karena itu, pengkajian semacam ini perlu dikembangkan oleh civitas kampus agar membangkitkan ruh-ruh penyemangat kebangkitan pendidikan Islam di negeri tercinta Indonesia. Bagi masyarakat luas, paling tidak kajian semacam ini memberikan informasi yang memadai tentang sepak terjang lembagalembaga pendidikan dalam berpartisipasi mencerdaskan kehidupan bangsa.

\section{DAFTAR RUJUKAN}

Departemen Pendidikan Nasional. (2008). Kamus Besar Bahasa Indonesia. Jakarta: Gramedia Pustaka Utama.

F.N., R. (2008). Bunga Rampai Pendidikan Islam. Jakarta: Pusat Kajian Islam FAI UHAMKA.

Haedari, M. A., \& El-Saha, M. I. (2004). Panorama Pesantren Dalam Cakrawala Modern. Jakarta: Diva Pustaka.

Hamalik, O. (2006). Manajemen Pengembangan Kurikulum. Bandung: UPI, PT Remaja Rosdakarya.

Kementrian Pendidikan dan Kebudayaan. (2003). Undang-Undang Republik Indonesia Nomor 20 Tahun 2003. Sistem Pendidikan Nasional. Retrieved from https://kemenag.go.id/file/dokumen/UU2003.pdf

Menteri Komunikasi dan Informatika Republik Indonesia. (2014). Peraturan Menteri Komunikasi Dan Informatika Republik Indonesia. Tata Cara Pendaftaran Penyelenggara Sistem Elektronik . Retrieved from file://E:/1413368416-merged_document_14.pdf

Muthohar, A. (2007). Ideologi pendidikan pesantren : pesantren di tengah arus ideologi-ideologi pendidikan : ikhtiar memotret \&amp; mencari formulasi baru sistem pendidikan pesantren dalam berbagai ideologi pendidikan kontemporer. Semarang: Pustaka Rizki Putra.

Siagian, S. P. (2005). Manajemen Sumber Daya Manusia. Jakarta: Bumi Aksara. 
Suryanegara, A. M. (2010). Api Sejarah. Bandung: Salamadani.

Zarkasyi, A. S. (2005a). Gontor dan Pembaharuan Pendidikan Pesantren. Jakarta: PT Rajawali Press.

Zarkasyi, A. S. (2005b). Pendidikan Pesanntren Era Modern. Retrieved August 16, 2017, from https://www. gontor.ac.id/k-h-dr-abdullah-syukri-zarkasyi-ma 